\title{
WILDLIFE CHANGES IN SOUTHEASTERN SASKATCHEWAN
}

HARRY A. STELFOX, 6232 - 127th Street, Edmonton, Alberta, T6H 3W9.

Historical changes in game populations over the last 100 years have been evaluated as part of an inventory of wildlife habitat made in southeastern Saskatchewan. ${ }^{26}$ This study has helped us to understand more fully the nature of present populations and to predict future trends. Prior to the early 1800's animal populations were little influenced by man, but fluctuated naturally in response to changes in climate and habitat conditions. With the coming of the fur trade and subsequent land settlement, much more substantial and permanent changes in numbers and distribution occurred.

The area that I am reporting on in this paper is the hilly Moose Mountain Upland and the gently undulating Souris River Plain (Fig. 1). The hummocky "knob and kettle" topography of the central portion of Moose Mountain has a scattering of ponds and lakes left from the melting of glacial ice some 20,000 years ago. ${ }^{16}$ It is now largely an aspencovered area, contained within Moose Mountain Provincial Park. The steep-sloping southern escarpment of the Upland supports open prairie grassland, cut by shrub and tree-filled coulees. The plains to the south and east have fertile black soils which are largely cultivated for the production of annual grain crops and perennial tame grasses. The remaining is that of the native vegetation, mixed-grass prairie and aspen parkland. The study area embraces portions of three major valleys through which flow the Souris River, Pipestone Creek and Moose
Mountain Creek. Numerous shallow ponds and sloughs are scattered through the farmlands.

\section{Pre-Settlement (prior to 1880)}

Prior to settlement the Souris River Plain was dominated by a treeless mixed-grass prairie. Owing to frequent prairie fires, woody vegetation usually disappeared except in moist depressions, sloughs, drainage systems and valleys. Moreover, Indians "fired" the prairie on a regular basis to influence American bison* movements and range conditions. ${ }^{1018}$ The central Moose Mountain Upland and the northfacing slopes of the Pipestone Creek and Souris River valleys provided the only substantial woody cover in the area. Vast herds of bison and many smaller bands of pronghorn called "cabri" in the early days, were the dominant ungulates. ${ }^{10} 2518$ Whitetailed jackrabbits, badgers, red and swift foxes, coyotes, ground squirrels, Upland Sandpipers, grassland passerine birds and Sharp-tailed Grouse were also typical prairie species. ${ }^{24} 1927$ Muskrats, Sandhill Cranes, Whooping Cranes and a variety of ducks and other marsh birds occupied the numerous prairie sloughs. ${ }^{17}$ Ferruginous and Swainson's hawks, Golden Eagles, Common Ravens, ${ }^{13}$ and Turkey Vultures were common predators and scavengers. Wapiti

*The common names of mammals referred to in the text follow those used in The Mammals of Canada. ${ }^{3}$ 


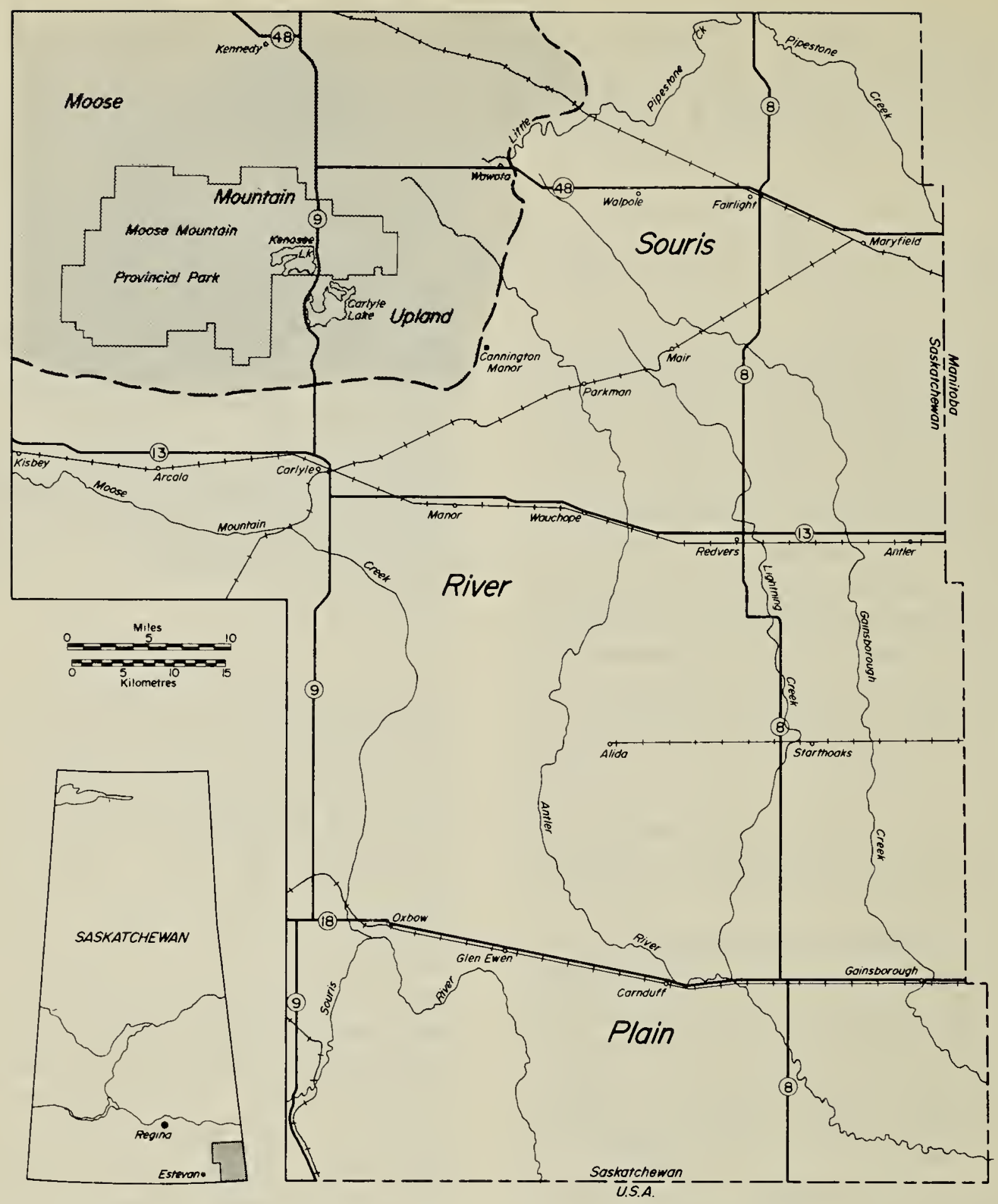

Figure 1: Study area located in the southeast corner of Saskatchewan.

(elk), moose, mule deer, mountain lions (cougars) and black bears stayed closer to the wooded portions of the Moose Mountain Upland and the Pipestone Creek and Souris River valleys. White Pelicans, Double-crested Cormorants and Great Blue Herons frequented the secluded lakes of Moose Mountain. Other species which were no doubt also former residents of the area, given their known earlier breeding range and habitat preferences, included wolves, grizzly bears, wolverines, river otters, Trumpeter Swans, Bald Eagles and Passenger Pigeons. ${ }^{29} 67327$

\section{0 to 1900}

Bison declined rapidly during the mid-1800's as a result of excessive hunting. ${ }^{18}$ The last one in the area was reported to have been killed by $1881 .^{9}$ Hunting pressures then shifted to other big game species. Moose reportedly disappeared from Moose Mountain in the late 19th cen- 


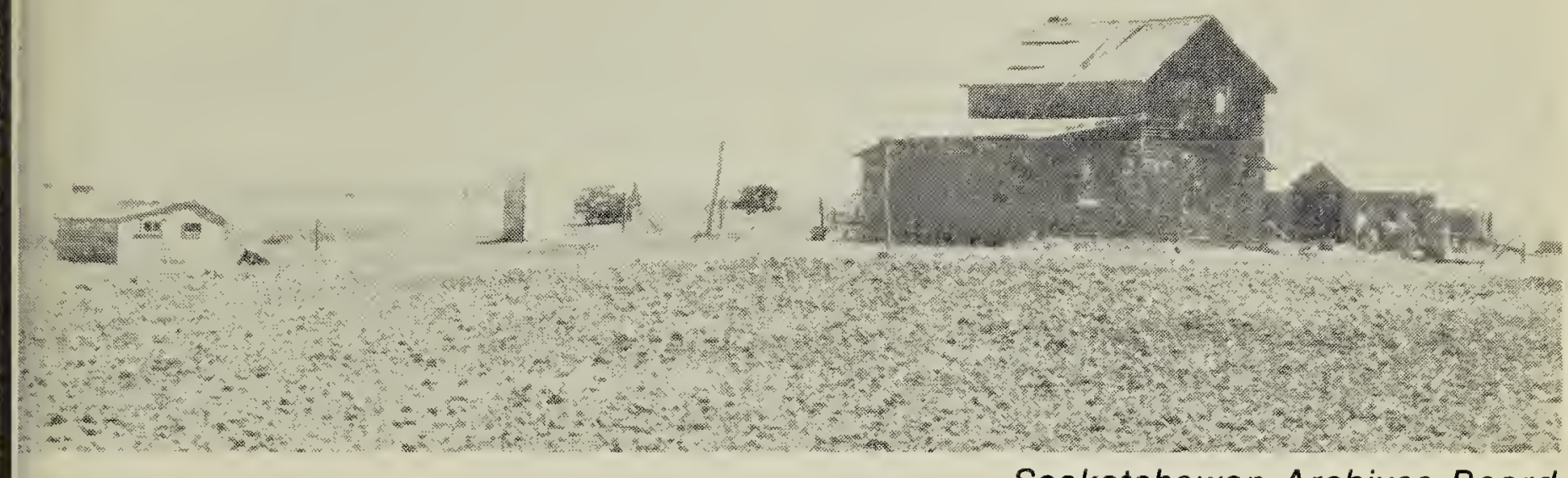

Saskatchewan Archives Board

Figure 2: Farmstead on predominantly treeless prairie around the 1920's.

tury, perhaps as a result of both organized drives and hunts by bands of Indians from the surrounding territory ${ }^{11}$ and an extensive fire that burned off much of the tree cover in 1894..$^{9}$ An early settler reported that in 1882 elk, deer, a few bears, beavers, lynx, muskrats, mink, fishers, and foxes, occurred in the Moose Mountain area, but that there were no moose. ${ }^{8}$

\section{0 to 1920}

The early 1900's were noteworthy for the general absence of big game, particularly in the open treeless plains (Fig. 2). Pronghorns were still present but in very diminished numbers as settlement and agricultural development became widespread and pushed them back owards the less arable rangeland to the south and west. Deer (principally mule deer) were uncommon and largely restricted to the rugged and partially wooded river valleys and Moose Mountain Upland. The first white-tailed deer to occur in the area robably moved in along the wooded iver valleys from adjacent Manitoba and North Dakota during this period. ${ }^{4}$

On Moose Mountain, elk were reported to be uncommon but still more numerous than deer, whereas muskrats, mink, weasels, striped skunks, coyotes, snowshoe hares, red squirrels and Sharp-tailed Grouse were abundant. Beaver populations were still depressed as a result of excessive trapping. Ruffed Grouse were reportedly common in the Pipestone Creek Valley but may have been less so in Moose Mountain until the aspen forest became more mature. A few moose reappeared in the Upland during the 1910's. ${ }^{9}$

Jack rabbits, foxes and badgers were more common in the surrounding plain. Sharp-tailed Grouse were very abundant and the Greater Prairie Chickens were common and widespread at this time. One early resident reported that Sharp-tailed Grouse dancing grounds were on nearly every quarter-section of land in the Parkman area. Greater Prairie Chickens did not occur in Saskatchewan prior to the 1900's but moved in with early settlement. ${ }^{29} 27$ The tem- 
porary success of this bird coincides with a period when native prairie vegetation was particularly luxuriant, with taller grass species favoured. Fire had been largely checked by early settlers and grazing pressure by wild game and livestock was minimal, as bison had been eliminated and cattle were still not numerous. ${ }^{21}$ Ducks were abundant and Sandhill Cranes were still common, nesting in the numerous potholes; however, Whooping Cranes now appeared only during migration. ${ }^{22}$ A few grey foxes were trapped in 1914 northeast of Carnduff and eastern cottontail rabbits were reported from the Storthoaks area about this same time.

\section{0 to 1940}

During the 1920's and 1930's several wildlife species increased in numbers while a few others virtually disappeared. With land settlement and the curtailment of prairie fires, aspen "bluffs" sprung up on uncultivated lands and were soon occupied by white-tailed deer. ${ }^{20}$ By the late 1930's whitetails were common, being well adapted to agricultural settlement wherever there was sufficient woody cover. In contrast, the mule deer's preference for more open terrain and susceptibility to hunting pressure kept populations low and restricted to the more rugged and hilly terrain.

Greater Prairie Chickens declined as rapidly as they had arrived about 30 years earlier ${ }^{7}$ and were apparently gone from the Storthoaks area by the late 1920's. Similar declines were observed in the crane populations, with the last regular migrant Whooping Cranes observed in the late 1920's.

The first Gray (Hungarian) Partridge and Ring-necked Pheasant appeared in the Redvers-Wawota area during the 1920's before an known stocking programs were un dertaken. ${ }^{20}$ Houston $^{12}$ reported the Hungarian Partridge spread naturall from Alberta, where they were initial ly released in 1908, to Saskat chewan, reaching "beyond Carlyle $t$ the Manitoba boundary" by 1927 Huns survived well and were report ed as locally abundant in the 1930's whereas Ring-necked Pheasant temporarily disappeared for severa years after their initial appearance.

Sharptails were still very abundan and benefitted from the large amoun of "go-back-land" during the 1930" when drought conditions cause many farms to be abandoned and revert to weeds and nativ vegetation. These drought condition were not favorable to waterfowl anc muskrats as a high proportion of the wetlands dried up. During this period coyotes became very abundant, ap. parently favoured by increased woody cover, whereas red foxes declined.

Moose Mountain Provincial Parl was established in 1931 and pro. vided the additional protection needed for moose, elk and beavel populations to recover..$^{15}$ Elk were already benefitting from a province. wide closure of hunting since $1919^{1}$ and herds of 30 to 40 animals were common by the mid-1930's. Beavel populations had previously been vir. tually wiped out by over-trapping sc stocking programs were used a Moose Mountain to aid theil recovery. Nesting populations o Common Loon, Double-crested Cormorant and Great Blue Heron occurred in the park during the mid1930's and White Pelicans were alsc frequently observed, although no known to nest.

\section{0 to 1960}

During the 1940's and 1950's 
The very wet years of the 1950's reduced upland game bird nesting and fledgling success but greatly increased waterfowl production. ${ }^{28}$ However, the previous burning and grazing of marshes and draining large sloughs had already spelled the end of nesting by Sandhill Cranes and they were now observed only during migration. ${ }^{22}$

\section{0 to 1979}

During the 1960's and 1970's the natural increase in tree growth was reversed by intensive, highlymechanized farming practices which removed the small patches of native vegetation as well as many of the quarter and half-sections which had never been broken? (Fig. 4). Tree cover on five unbroken parcels of land totalling $2 \frac{1}{4}$ sections in the Parkman-Maryfield area averaged $31 \%$ in 1949 and $48 \%$ in 1970 representing a $1.7 \%$ increase per year $^{26}$ (Figs. 5 and 6). However, that portion of the occupied farmland in the Redvers-Maryfield-Kelso area which still remained in native vegetation declined from $38 \%$ in 1949 to $28 \%$ in 1977 , representing a $26 \%$ decline in total or $0.9 \%$ per year. The 1970-77 average rate of loss to cultivation was even higher at $1.6 \%$ per year. At the same time large machinery drained or filled many of the wetlands.

These habitat alterations have resulted in a widespread and apparently permanent decline in upland game bird and waterfowl populations. Upland game birds feeding on waste grain were also hit by the extensive use of grasshopper poison and mercury seed dressings ${ }^{5}$ in the 1960 's which resulted in substantially lowered reproductive success. With curtailment in the use of these toxic substances during the 1970's game bird numbers recovered to a considerable extent with Sharptails be- ing quite abundant and Huns com mon. Ruffed Grouse recently peake (1976-78) in their 10-year cycle an were reported to have been mor abundant in the Storthoaks area tha at any time during the previous 6 years. However, Ring-necke Pheasant populations have remaine very low with average winter weathe conditions likely being too severe.

Long term population trends fo white-tailed deer are not so cleal Mortality was very high during th severe winter of $1973-74 .{ }^{25}$ Howevel populations recovered quickly wit the aid of two mild winters. ${ }^{26}$ The con tinued loss of suitable native habita has caused whitetails to feed mor and more on agricultural crops dur ing the winter season. Mortality o reduced productivity from sever winter weather is potentially muc greater now as suitable blocks cover within agricultural areas (nativ aspen parkland one-quarter sectio or more in size) become fewer an farther apart. $^{26}$

Grey squirrels first appeared in th Storthoaks area in the 1960's an became fairly common in the 1970's Coyotes have continued to decline i recent years as the result of heav hunting and trapping pressur whereas red fox populations ar recovering. Lynx are not known to $b$ permanent residents of the area by occasionally move in from the north Frequent sightings were made in th early 1970's and two were shot nea Moose Mountain in 1970 and anothe two near Storthoaks in 1974 Cougars are still occasionally sighter in the Moose Mountain area ( $T$ White, pers. comm.) and both adult and young of the year were observer near Antler in 1970 and 1972. ${ }^{30}$

In the Moose Mountain Upland moose and elk numbers hav stabilized $^{26}$ as a result of carefull. managed harvests. Beaver have 


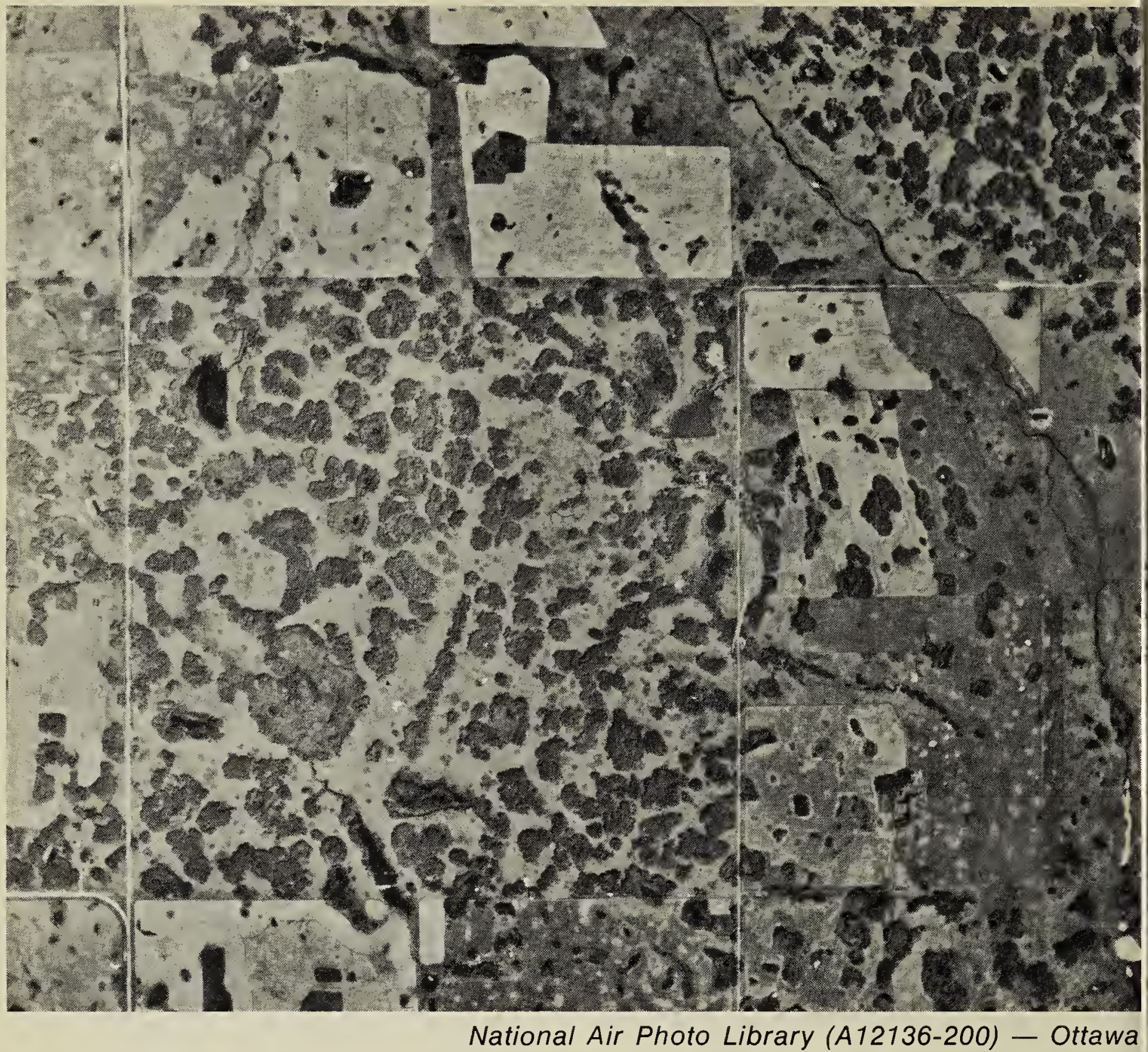

Figure 5: Aerial photo from 1949 of Sec. 29 - Twp. 10 - Rge. 30-W1, one mile north of Maryfield. Dark patches represent aspen bluffs.

vegetation. Fire was curtailed, grazing pressure was altered, woody vegetation invaded grassland, prairie was cultivated, wetlands were drained and filled, and brush was cleared. The eventual trend was towards a more homogeneous and simplified environment which no longer had the capability to support the same variety and numbers of wildlife as in former times.

Most wildlife species for which we have data are currently below previous population levels (Fig. 7). Continued agricultural developments which result in the further removal of natural vegetation and the creation of a less diversified landscape will probably result in the continued decline and possible disappearance of more wildlife species. With the aid of past observations and experiences a long term strategy for the future must be developed whereby we secure the essential wildlife habitat mosaics which still remain and restore some of the natural diversity which we have lost.

\section{Acknowledgements}

Thanks to G. Duff who drafted the figures and J. B. Gollop, C. S. Houston and G. W. Pepper who reviewed several drafts of the 


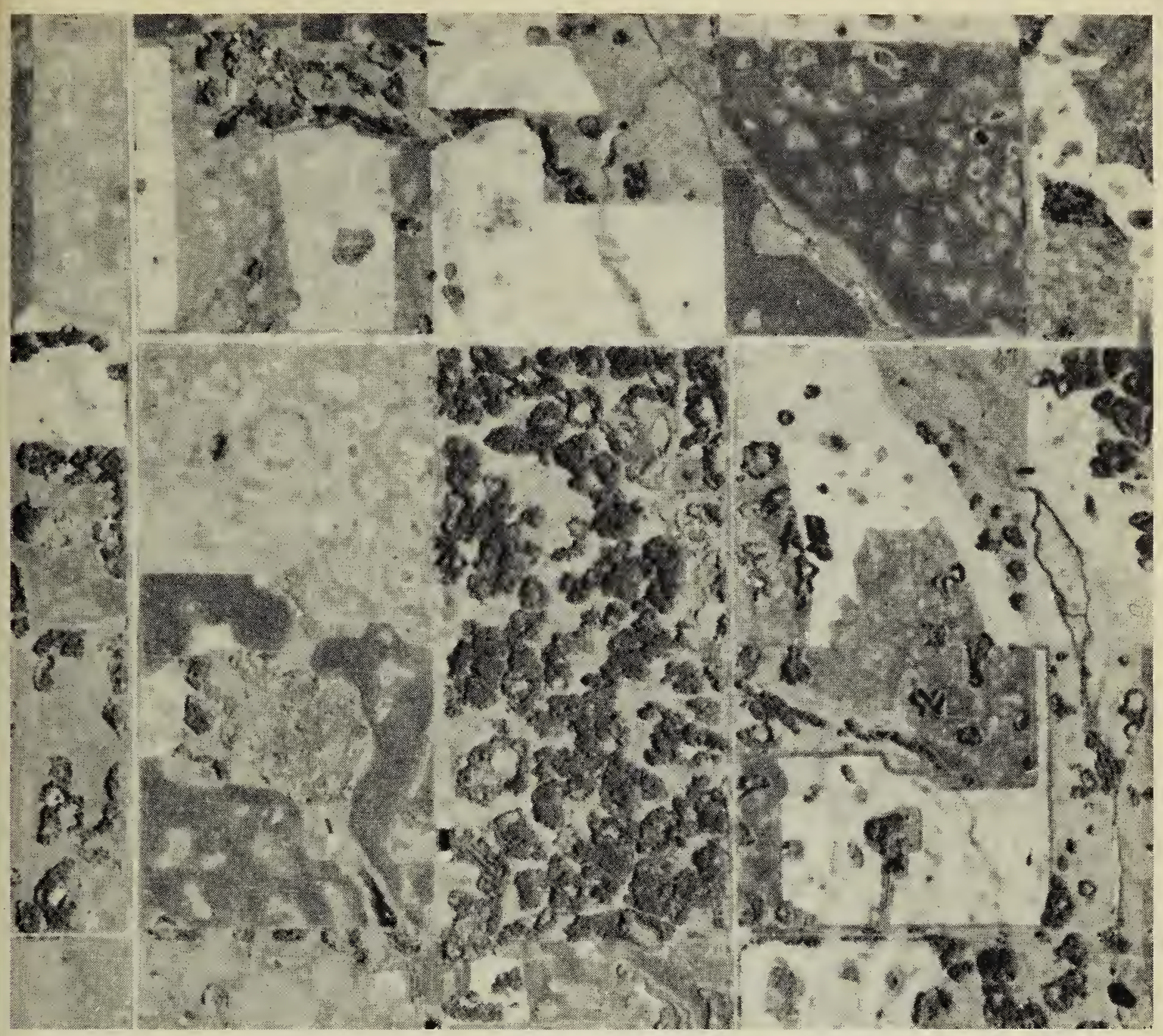

National Air Photo Library (A21794-24) - Ottawa

Figure 6: Aerial photo from 1970 of the same parcel of land shown in Figure 5. Note the removal of aspen and increased area of cultivation, as well as increases in the size of aspen bluffs which were not cleared.

manuscript. Also a special thanks to the numerous residents of the study area who provided the author with personal observations of wildlife and land use changes since early settlement: F. Baran, R. Barber, $H$. Coté, K. Cummins, A. Dennis, L. Dennis, W. Hill, J. Lees, D. C. McCormick, W. Mills, H. J. Munro, K. Racz, F. Thompson, E. J. Turton, H. Weatherald, T. White, T. Wilson. E. Kennett was particularly helpful in arranging several interviews.

${ }^{1}$ ALLEN, D. L. 1967. The life of prairies and plains. McGraw-Hill Inc., New York. 232 pp.
${ }^{2}$ BAINES, K. E. 1956. The ups and downs of game at Crescent Lake. Blue Jay 14(2):65-66.

${ }^{3}$ BANFIELD, A. W. F. 1974. The mammals of Canada. Univ. Toronto Press, Toronto. $438 \mathrm{pp}$.

${ }^{4}$ BIRD, R. D. 1961. Ecology of the aspen parkland of western Canada in relation to land use. Can. Dep. Agric. Res. Br. Contr. 27. Ottawa. 155 pp.

${ }^{5}$ FIMREITE, N. 1971. Effects of dietary methylmercury on ring-necked pheasants. Can. Wildl. Ser. Occas. Paper No. 9. Ottawa. 39 pp.

${ }^{6}$ GODFREY, W. E. 1966. The birds of Canada. Nat. Mus. Can. Bull. 203, Biol. Series 73. Ottawa. 428 pp. 
Reiative Proportion of Land Use Categories

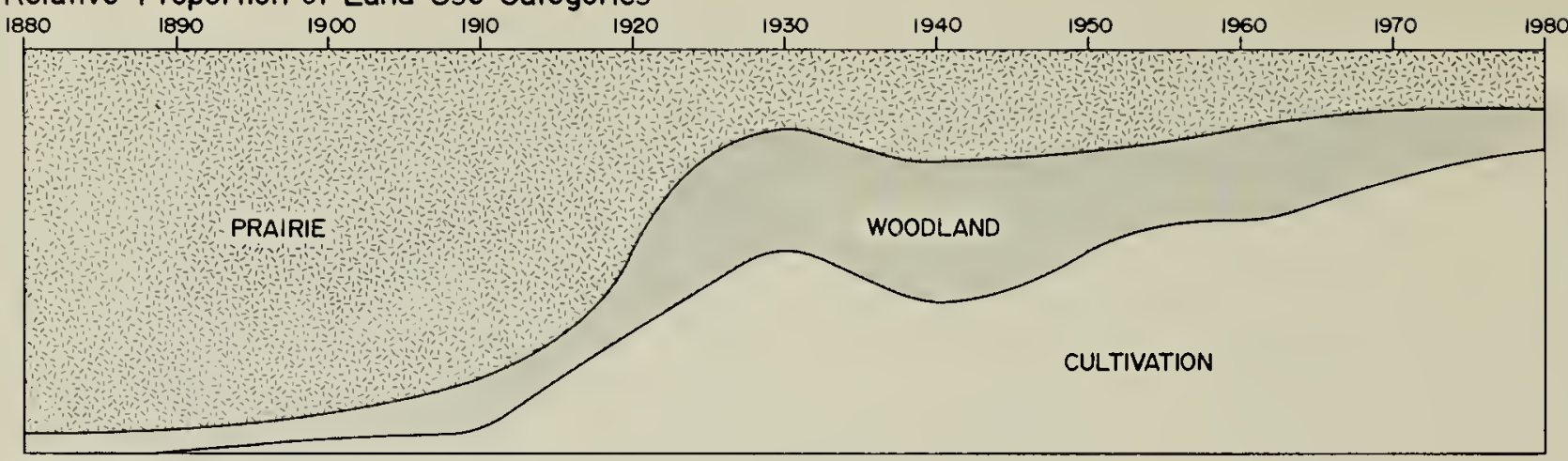

\section{Reiative Population Levels*}

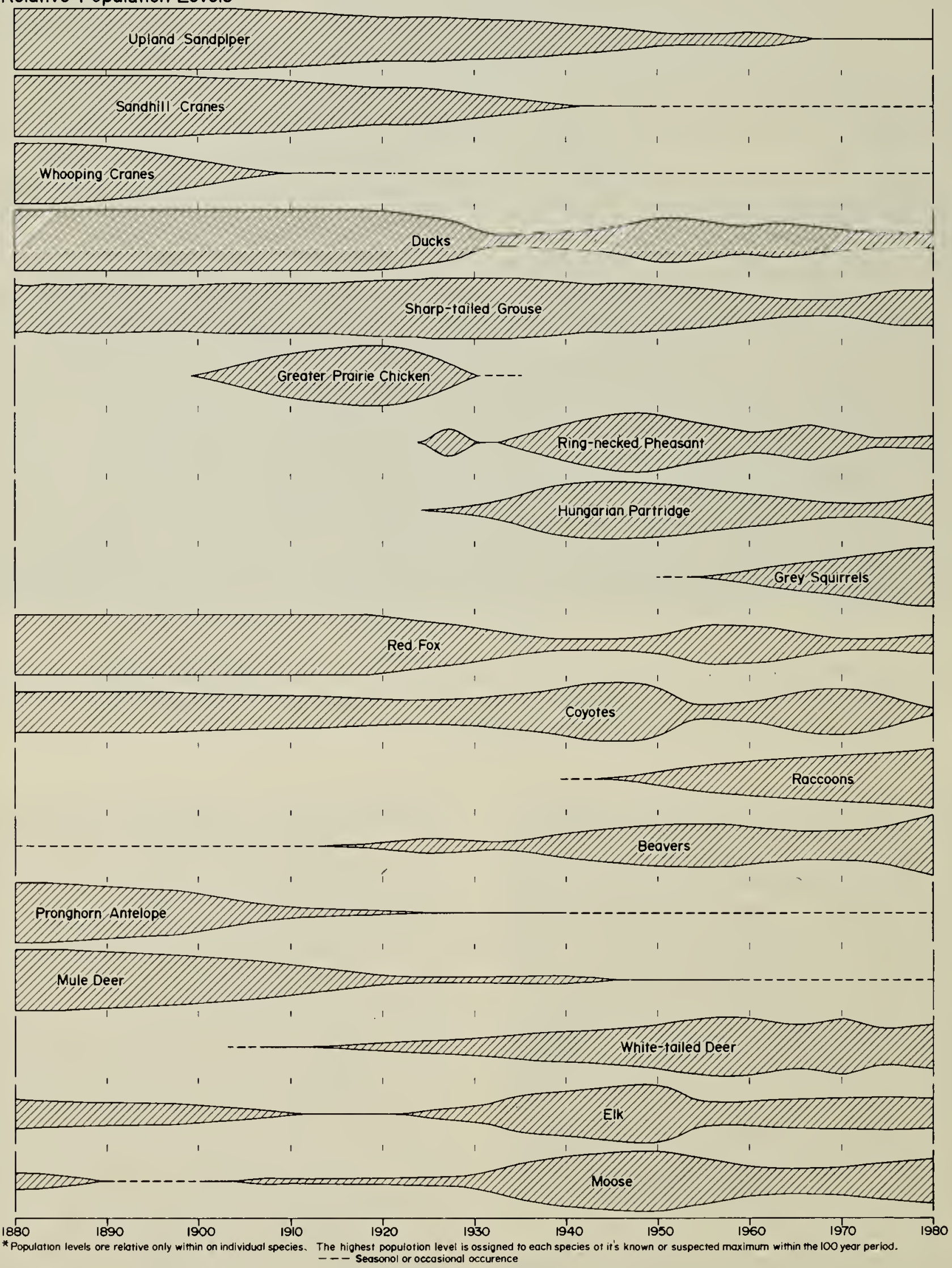

Figure 7: Diagramatic summary of relative changes in land use and wildlife populations in southeastern Saskatchewan from 1880 to 1980. 
${ }^{7}$ GOLLOP, J. B. 1969. Birds in Saskatchewan. In J. H. Richards and K. I. Fung, Atlas of Saskatchewan. Univ. of Sask., Saskatoon. 263 pp.

${ }^{8}$ HEWLETT, A. E. M. N.d. Chipman Hill notes in Old Timers of Moose Mountain rather than Cannington proper. Shortt Library of Canadiana, Univ. Sask., Saskatoon. Cat. No. MSS C555/2/14.11 No. 23. N. IV-4 \& 5.

${ }^{9}$ HEWLETT, A. E. M. 1970. A too short yesterday. Western Producer. Saskatoon. 161 pp.

${ }^{10} \mathrm{HIND}, \mathrm{H}$. Y. 1859. Northwest Territory. Reports on progress; together with a preliminary and general report on the Assiniboine and Saskatchewan exploring expeditions ... John Lovell, Toronto. 201 pp.

"HISLOP, M. and A. MCLENNAN. 1955. When scalping ceased and buffaloes disappeared. Moose Mountain StarStandard. July 6, 1955.

${ }^{12}$ HOUSTON, C. S. 1976. Wildlife. Fish and Game Sportsman, 8(1):78-79.

${ }^{13}$ HOUSTON, C. S. 1977. Changing patterns of Corvidae on the prairies. Blue Jay 35(3):149-156.

${ }^{14}$ HUNT, H. M. 1979. The ecology and status of elk in Saskatchewan. Unpubl. mimeo. Sask. DTRR. 68 pp.

${ }^{15}$ INTERA Environmental Consultant Ltd. 1978. Moose Mountain Park resource inventory and analysis. Prepared for Sask. DTRR. 120 pp. + 5 appendices.

${ }^{16} \mathrm{KUPSCH}$, W. O. 1969. Glacial geology (quaternary) of Saskatchewan. In J. H. Richards and K. I. Fung, eds. Atlas of Saskatchewan. Univ. Sask., Saskatoon. 236 pp.

${ }^{17}$ MACOUN, J. 1882. Manitoba and the great northwest. World Publishing Co., Guelph. 687 pp.

${ }^{18}$ NELSON, J. G. 1973. The last refuge. Harvest House, Montreal. 202 pp.

${ }^{19}$ NERO, R. W. and M. R. LEIN. 1971. Birds of Moose Mountain, Saskatchewan. Sask. Nat. His. Soc., Spec. Publ. No. 7. Regina. 55 pp.
${ }^{20}$ NIXON, M. 1973. Then and now. Blue Jay 31(1):4-6.

${ }^{21}$ PEPPER, G. W. 1978. Wildlife of Saskatchewan - past, present and future. Pages 111-119 in W. A. Davies ed. Nature and change on the Canadian plains. Proceedings of the 1977 annual meeting of the Canadian Nature Federation. Can. Plains Resear. Center. Univ. Regina, Regina. $201 \mathrm{pp}$.

${ }^{22}$ PITTMAN, H. H. 1956. Sandhill cranes in restrospect. Pages 237-239 in Nature Magazine (Am. Nature Assoc., Washington D.C.). Vol. 49, No. 5.

${ }^{23}$ RUNGE, W. and G. WOBESER. 1976. Winter deer mortality study. Sask. Dep. Tourism and Renew. Resour., Wildl. Tech. Rep. 76-1. 19 pp.

${ }^{24}$ SETON, E. T. 1909. Life histories of northern animals - an account of the mammals of Manitoba. Charles Scribner's Sons, New York City. 2 Vols. $1267 \mathrm{pp}$.

${ }^{25}$ SPRY, I. M. 1963. The Palliser expedition: an account of John Palliser's British North American expedition 1857-1860.

${ }^{26}$ STELFOX, H. A. 1979. Terrestrial wildlife habitat inventory of the Weyburn (62E) - Virden (62F) map area. Sask. Dep. Tourism and Renew. Resour., Wildl. Tech. Rep. 79-6. 213 pp.

${ }^{27}$ STEWART, R. E. 1975. Breeding birds of North Dakota. Tri-college Center for Environmental Studies. Fargo, N.D. $295 \mathrm{pp}$.

${ }^{28}$ STOUDT, J. H. 1971. Ecological factors affecting waterfowl productions in the Saskatchewan parklands. U.S. Dept. of Interior, Bur. Sport Fish. and Wildl. Resource Publ. 99. 58 pp.

${ }^{29}$ THOMPSON, E. E. 1891. The birds of Manitoba. Proc. U.S. Natl. Mus. 13:457-643. Reprint 1975. Premium Ventures Ltd., Winnipeg.

${ }^{30}$ WHITE, T. 1973. Cougar kittens reported near Antler, Saskatchewan. Blue Jay 31(1):42-43. 